\title{
Avirulence genes and mating types in the populations of Leptosphaeria maculans collected from infected oilseed rape plants in Poland in autumn 2010
}

\author{
Geny awirulencji i typy kojarzeniowe \\ w populacjach Leptosphaeria maculans \\ zebranych z porażonych roślin rzepaku w Polsce jesienią 2010 roku
}

Joanna Kaczmarek ${ }^{1}$, Andrzej Brachaczek ${ }^{2}$, Deng Shu ${ }^{1}$, Witold Irzykowski ${ }^{1}$, Małgorzata Jędryczka ${ }^{1}$

\begin{abstract}
Summary
The fungi Leptosphaeria maculans and L. biglobosa cause stem canker - one of the most damaging diseases of oilseed rape in Poland and worldwide. The aim of this study was to characterize the composition of avirulence genes and mating types present in current populations of L. maculans in Poland. The study was done in autumn 2010. The isolates of L. maculans (254) were obtained from infected winter rapeseed leaves collected at six locations. DNA (deoxyribonucleic acid) of each isolate was extracted using a CTAB (cetyltrimethyl ammonium bromide) method. The taxonomic identity of isolates was checked by RAPD (random amplification of polymorphic DNA) using OPJ-10 primer and compared with specific banding patterns characteristic for the representatives of L. maculans and L. biglobosa. Isolates of L. maculans were studied to identify a mating type and avirulence alleles AvrLm1 and AvrLm6. Mating types MAT1.1 and MAT1.2 were found in similar frequencies at all sites, what suggests that both types are well adapted to environment. The AvrLm1 avirulence allele was observed only in isolates obtained at one collection site. For the first time in Poland the avrLm6 virulence allele has been found.
\end{abstract}

Key words: resistance gene, avirulence gene, Leptosphaeria maculans, Leptosphaeria biglobosa, mating type, winter oilseed rape

\section{Streszczenie}

Grzyby Leptosphaeria maculans i L. biglobosa powodują suchą zgniliznę kapustnych - jedną z najgroźniejszych chorób rzepaku w Polsce i na świecie. Celem tych badań było określenie składu genów awirulencji i typów kojarzeniowych w populacjach $L$. maculans aktualnie występujących w Polsce. Badania prowadzono jesienią 2010 roku. Z porażonych liści rzepaku ozimego pobranych w sześciu miejscach uzyskano 254 izolaty L. maculans. DNA (deoxyribonucleic acid - kwas deoksyrybonukleinowy) izolatów ekstrahowano przy zastosowaniu metody CTAB (cetyltrimethyl ammonium bromide - bromek heksadecylotrimetyloamoniowy). Przynależność taksonomiczną sprawdzano przy zastosowaniu metody RAPD (random amplification of polymorphic DNA - metoda losowej amplifikacji polimorficznych fragmentów DNA) z użyciem startera OPJ-10 i porównywano z wzorem produktów PCR (polymerase chain reaction - reakcja łańcuchowa polimerazy), charakterystycznych dla izolatów wzorcowych dla L. maculans i L. biglobosa. Izolaty L. maculans oznaczano pod względem przynależności do typu kojarzeniowego i określano ich allele awirulencji AvrLm1 i AvrLm6. Typy kojarzeniowe MAT1.1 i MAT1.2 występowały w podobnych proporcjach we wszystkich populacjach, co sugeruje, że oba są dobrze przystosowane do środowiska. Allel awirulencji AvrLm1 obserwowano tylko u izolatów zebranych w jednej lokalizacji. Po raz pierwszy w Polsce stwierdzono allel wirulencji avrLm6.

Słowa kluczowe: gen odporności, gen awirulencji, Leptosphaeria maculans, Leptosphaeria biglobosa, typ kojarzeniowy, rzepak ozimy

\footnotetext{
${ }^{1}$ Instytut Genetyki Roślin Polskiej Akademii Nauk

Strzeszyńska 34, 60-479 Poznań

mjed@igr.poznan.pl

${ }^{2}$ DuPont Poland Sp. z o.o.

Postępu 17b, 02-676 Warszawa

andrzej.brachaczek@pol.dupont.com
} 


\section{Wstęp / Introduction}

Grzyb Leptosphaeria maculans jest przyczyną suchej zgnilizny kapustnych, jednej z najgroźniejszych chorób rzepaku w Polsce i na świecie (Fitt i wsp. 2006; Jędryczka 2006). Wiedza na temat struktury populacji tego patogena, występującej na danym terenie, a zwłaszcza dotycząca zestawu genów awirulencji, ma duże znaczenie praktyczne dla kierunku prac prowadzonych $\mathrm{w}$ zakresie hodowli odpornościowej rzepaku.

Geny awirulencji (Avr) występują u wielu gatunków grzybów. Zgodnie z hipotezą gen-na-gen produkty genów awirulencji (elicitory) wchodzą w interakcję z produktami określonych genów odporności u roślin uprawnych. W wyniku oddziaływania produktów tych genów nie dochodzi do procesu chorobowego (Laugé i De Wit 1998). Najczęściej kontakt elicitorów z receptorami rośliny gospodarza prowadzi do reakcji nadwrażliwości. Niektóre z genów awirulencji zdołano wyizolować, sklonować i zmapować w genomie patogena. Badania wykazały, że produktami dotychczas opisanych genów awirulencji były zazwyczaj niewielkie białka, wydzielane pozakomórkowo (Joosten i De Wit 1988; Wubben i wsp. 1994; Gout i wsp. 2006; Fudal i wsp. 2007).

Badania składu populacji L. maculans we Francji wykazały, że wprowadzenie genu odporności $\operatorname{Rlml}$ na prawie połowie powierzchni uprawnej rzepaku $(43,7 \%$ w 1997 roku) spowodowało presję selekcyjną, której efektem był dramatyczny spadek udziału izolatów z genem awirulencji AvrLm1 (o 70\%) na rzecz wirulentnych szczepów avrLm1. W ciągu dwóch sezonów wegetacyjnych udział genotypu AvrLm1 zmniejszył się z 83\% do 13\% (Rouxel i wsp. 2003), co wskazuje, że przystosowanie patogena do nowej sytuacji $\mathrm{w}$ polu może następować w bardzo szybkim tempie.

Dotychczas u L. maculans zmapowano dziewięć genów awirulencji w czterech niezależnych grupach sprzężeń (Balesdent i wsp. 2006). Pierwszy gen awirulencji u L. maculans oznaczono jako AvrLml (Ansan-Melayah i wsp. 1995). Klonowanie tego genu poprzedzono sekwencjonowaniem dużego obszaru genomu wokół AvrLml. Stwierdzono, iż jest on znacznie oddalony od innych genów i znajduje się w środku dużego regionu o cechach heterochromatyny (Gout i wsp. 2006). Prowadzone badania wykazały brak homologów AvrLm1 zarówno u gatunków blisko spokrewnionych z L. maculans, jak i w innych znanych genomach grzybów. Podobnie jak geny odporności u roślin, geny awirulencji są zlokalizowane blisko siebie. Gen AvrLm1, tak jak gen AvrLm6 jest także umiejscowiony $\mathrm{w}$ obszarze niekodującym. Ponadto AvrLm1 i AvrLm6 charakteryzuje niewielka proporcja par GC, co odróżnia je od większości grzybowych genów awirulencji (Gout i wsp. 2006).

Grzyb L. maculans jest rozdzielnopłciowy i posiada pojedyncze locus typu kojarzeniowego (MAT) (Venn 1979). Gen MAT1.1 ma wielkość 1368 pz, zawiera intron o długości $45 \mathrm{pz}$ i koduje białko o wielkości szacowanej na 441 aminokwasów. Natomiast gen MAT1.2 o wielkości $1246 \mathrm{pz}$, zawiera intron o długości $55 \mathrm{pz}$, a przewidywana wielkość kodowanego białka wynosi 397 aminokwasów
(Cozijnsen i Howlett 2003). Wiedza na temat udziału alleli MAT1.1 i MAT1.2 w populacji L. maculans pozwala na oszacowanie możliwości ich swobodnego rozmnażania, czyli także utrzymywania wysokiego stopnia polimorfizmu genetycznego i tworzenia nowych ras.

\section{Materiały i metody / Materials and methods}

Próby liści roślin rzepaku $\mathrm{z}$ objawami suchej zgnilizny kapustnych zebrano z 6 pól w następujących lokalizacjach: Radostowo (N 5359'27,2", E 18²43'59,6"), Nowa Wieś

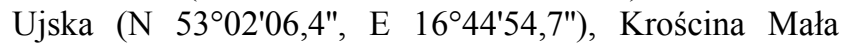

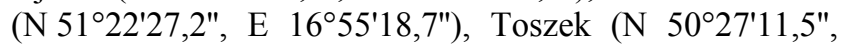

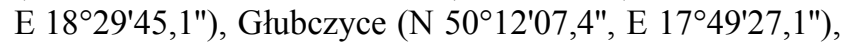
Walewice (N 52 $06^{\prime} 18^{\prime}, 8^{\prime}$, E 19³9'73,1'). Każdorazowo pochodziły one $\mathrm{z}$ odmiany mieszańcowej PR46W10 (Pioneer Hi-Bred) $\mathrm{z}$ wariantu kontrolnego. Liście dezynfekowano, a następnie $\mathrm{w}$ warunkach sterylnych wykładano na pożywkę agarową PDA (Potato Dextrose Agar) $\mathrm{z}$ dodatkiem $0,02 \%$ siarczanu streptomycyny. Po 2 dniach $\mathrm{z}$ wyrastającej kolonii grzyba pobierano pod binokularem (Stemi DR 1040, Zeiss, Niemcy) końcowy fragment pojedynczej strzępki w celu uzyskania izolatów jednolitych genetycznie. Fragment ten przenoszono na szalki ze świeżą pożywką PDA z dodatkiem antybiotyków, aż do uzyskania kultur wolnych od bakterii i innych patogenów. Czystość izolatów sprawdzano poprzez ich hodowlę na płynnej pożywce Czapka-Doxa z dodatkiem ekstraktu drożdżowego $(2 \mathrm{~g} / \mathrm{l})$. Po kilku dniach hodowli klarowna pożywka świadczyła o braku zanieczyszczeń bakteryjnych. Następnie na podstawie cech morfologicznych wstępnie identyfikowano gatunki $L$. maculans i L. biglobosa. DNA (deoxyribonucleic acid - kwas deoksyrybonukleinowy) izolatów ekstrahowano $\mathrm{z}$ wykozystaniem CTAB (cetyltrimethyl ammonium bromide bromek heksadecylotrimetyloamoniowy) i mieszaniny chloroformu oraz alkoholu izoamylowego $\mathrm{w}$ proporcji 24:1, według Grahama i wsp. (1994) z modyfikacjami własnymi. Przynależność taksonomiczną sprawdzano przy zastosowaniu metody RAPD (random amplification of polymorphic DNA - metoda losowej amplifikacji polimorficznych fragmentów DNA) z użyciem startera OPJ-10 (AAGCCCGAGG) i porównywano $\mathrm{z}$ wzorem produktów PCR (polymeraze chain reaction - reakcja łańcuchowa polimerazy) charakterystycznych dla izolatów referencyjnych obu badanych gatunków rodzaju Leptosphaeria. Izolaty L. maculans oznaczano pod względem przynależności do typu kojarzeniowego z wykorzystaniem starterów MAT1.1 (CTCGATGCAATGTACTTGG), MAT1.2 (AGCCGGCGGTGAAGTTGAAGCCG) i RevMAT (TGGCGAATTAAGGGATTGCTG) (Cozijnsen i Howlett 2003). Metodą PCR określano allele AvrLm1/avrLm1 i AvrLm6/avrLm6 za pomocą następujących starterów AvrLm1 qF (GGGTGTTTACTTCGCCTCAC), AvrLm1 qR (ACGTTGTAATGAGCGGAACC) i AvrLm6 qF (TATTGGACAAAAGCCGAAGG) oraz AvrLm6 qR (GCGAGAAGCAAGTGGAATGT) (Van de Wouw i wsp. 2010). 


\section{Wyniki i dyskusja / Results and discussion}

Określenie struktury populacji grzybów rodzaju Leptosphaeria jest ważnym elementem dobrej praktyki rolniczej związanej z ochroną tej uprawy. W Polsce zakres i nasilenie występowania obu patogenów jest zróżnicowany i podlega ciagłym zmianom. Dwadzieścia lat temu obserwowano niemal wyłącznie gatunek L. biglobosa, jednak od tamtego czasu obserwuje się wzrost udziału gatunku L. maculans i jego ekspansję z zachodu na wschód, przy czym nadal stwierdza się zmiany składu populacji patogenów w czasie i przestrzeni (Karolewski 1998; Jędryczka 2006). W badaniach prezentowanych $\mathrm{w}$ niniejszej pracy $\mathrm{z}$ pobranych prób uzyskano 288 izolatów, $\mathrm{z}$ czego 71 pochodziło z Radostowa, 52 z Krościny Małej, 50 z Toszka, 48 z Nowej Wsi Ujskiej, 43 z Głubczyc oraz 24 izolaty uzyskano z Walewic. Na podstawie wzoru produktów RAPD stwierdzono, iż średnio w badanej puli znajdowało się 87\% izolatów L. maculans i 13\% L. biglobosa. Największy odsetek izolatów L. maculans - przewyższający 90\%, odnotowano w Radostowie (93\%), Nowej Wsi Ujskiej (92\%) i w Toszku (92\%). W Walewicach - lokalizacji najbardziej wysuniętej na wschód, grzyb L. maculans był także dominujący na liściach rzepaku, ale stanowił on jedynie 75\% uzyskanych izolatów (rys. 1). Dominację grzyba L. maculans na liściach rzepaku wykazała Jędryczka (2006) w badaniach prowadzonych w latach 2000-2004, a następnie w latach 2009-2010 także Kaczmarek i wsp. (2011). Wykazano także, że proporcje pomiędzy gatunkami L. maculans i L. biglobosa w znacznym stopniu zależały od okresu, w którym wykonywano obserwacje, a co się $\mathrm{z}$ tym wiąże, są one różne, na poszczególnych organach roślinnych. W okresie jesiennym na liściach zwykle przeważał gatunek L. maculans, natomiast na łodygach dominował gatunek L. biglobosa.

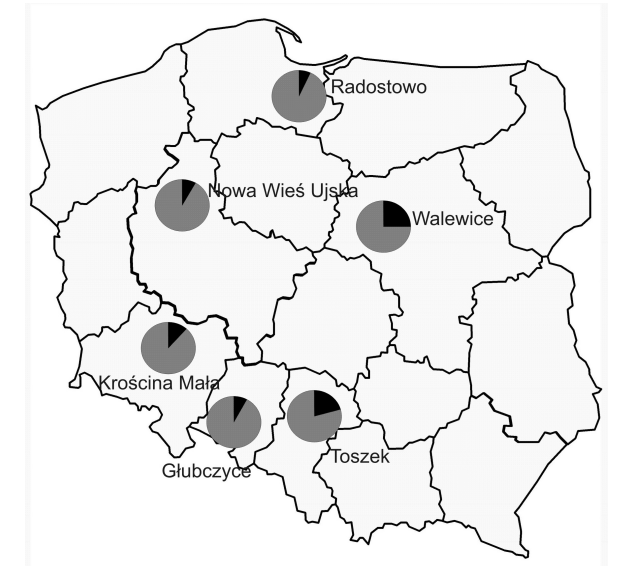

Rys. 1. Udział procentowy gatunków L. maculans (szary obszar) i L. biglobosa (czarny obszar) porażających rośliny rzepaku ozimego jesienią $2010 \mathrm{w}$ Polsce

Fig. 1. The percentage of L. maculans (grey area) and L. biglobosa (black area) in winter oilseed rape plants in autumn 2010 in Poland

Zastosowanie metody multiplex PCR z użyciem specyficznych starterów pozwoliło na oznaczenie przynależności danego izolatu L. maculans do określonego typu kojarzeniowego. Dla typu MAT1.1 startery amplifikowały fragment o długości $686 \mathrm{pz}$, natomiast w przypadku MAT1.2 długość amplifikowanego fragmentu wynosiła 443 pz (rys. 2).

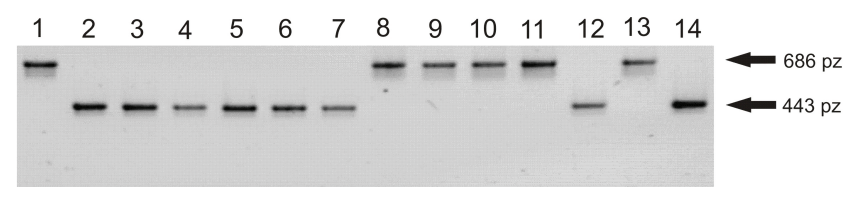

Rys. 2. Produkty uzyskane w wyniku reakcji PCR ze starterami MAT1.1, MAT1.2 i RevMAT z zastosowaniem genomowego DNA izolatów L. maculans. Symbole zastosowanych izolatów: 1 - izolat referencyjny dla MAT1.1, 2 izolat referencyjny dla MAT1.2, 3 - KM2010-1-1, 4 KM2010-1-2, 5 - KM2010-1-3, 6 - KM2010-1-4, 7 KM2010-1-5, 8 - KM-2010-1-6, 9 - KM2010-1-7, 10 KM2010-1-8, 11 - KM2010-1-9, 12 - KM2010-1-10, 13 - KM2010-1-11, 14 - KM2010-1-12

Fig. 2. The products obtained by PCR with primers MAT1.1, MAT1.2 i RevMAT using genomic DNA of L. maculans isolates: 1 - reference isolate for MAT1.1, 2 - reference isolate for MAT1.2, 3 - KM2010-1-1, 4 - KM2010-1-2, 5 - KM2010-1-3, 6 - KM2010-1-4, 7 - KM2010-1-5, 8 KM-2010-1-6, 9 - KM2010-1-7, 10 - KM2010-1-8, 11 KM2010-1-9, 12 - KM2010-1-10, 13 - KM2010-1-11, 14 - KM2010-1-12

May i wsp. (1999) udowodnili, iż występowanie genów $M A T$ uzależnione jest od selekcji izolatów w warunkach naturalnych. W przypadku, gdy typy kojarzeniowe występują w równych proporcjach, możliwe jest losowe krzyżowanie się w obrębie populacji (Milgroom 1996). Przewaga występowania lub brak jednego $\mathrm{z}$ typów kojarzeniowych w populacji powoduje ograniczenie lub całkowity brak możliwości rozmnażania płciowego w obrębie populacji. We wszystkich badanych lokalizacjach oba typy kojarzeniowe występowały w zbliżonych proporcjach, ale z przewagą typu MAT1.2. Izolaty należące do typu kojarzeniowego MAT1.2 stanowiły od 52,1\% (Nowa Wieś Ujska) do 61,5\% (Głubczyce) badanej populacji - średnio 56,3\% (rys. 3). Podobne wyniki uzyskano dla prób pobranych $\mathrm{z}$ pól doświadczalnych w północno-zachodniej Francji. Na 81 przebadanych izolatów L. maculans, 34 (42\%) reprezentowały typ MAT1.1, a 47 (58\%) należało do typu MAT1.2 (Gout i wsp. 2006). Równomierny rozkład występowania typów kojarzeniowych MAT1.1 i MAT1.2 we wszystkich badanych populacjach niezależnie od miejsca występowania sugeruje, iż grzyb L. maculans egzystuje w środowisku, które zapewnia mu optymalne warunki, odpowiadające obu typom kojarzeniowym.

Ze względu na posiadanie stadium płciowego izolaty L. maculans cechuje duża zmienność genetyczna. Gatunek ten tworzy liczne rasy, będące odmienną kombinacją genów awirulencji (AvrLm). Wirulentne izolaty grzyba (avrLm) mają zdolność przełamywania genów odporności rzepaku (Rlm). Układ taki określany jest jako kompatybilny lub zgodny. Jest to typ oddziaływania gen-nagen, w którym występuje współdziałanie i dopełnianie się genotypów wyspecjalizowanych patogenów i ich żywicieli. 


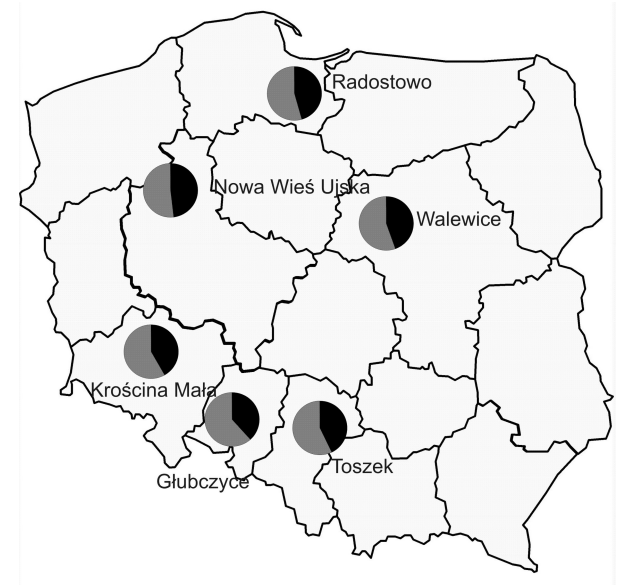

Rys. 3. Udział procentowy typów kojarzeniowych MAT1.1 (czarny obszar) i MAT1.2 w populacjach L. maculans $\mathrm{w}$ jesienią $2010 \mathrm{w}$ Polsce

Fig. 3. The percentage of mating type MAT1.1 (black area) and MAT1.2 (grey area) in the populations of L. maculans in autumn 2010 in Poland

Do tej pory obecność genów awirulencji u izolatów L. maculans można było oznaczyć na podstawie reakcji odmian i linii testowych rzepaku (Chen i Fernando 2006). Dzięki opracowaniu starterów specyficznych dla amplifikacji alleli genów AvrLm1 i AvrLm6 (Van de Wouw i wsp. 2010) możliwe jest ich oznaczenie z wykorzystaniem technik molekularnych. W obrębie uzyskanych izolatów jedynie w Krościnie Małej stwierdzono występowanie allelu AvrLm1 (14\%) (rys. 4). We wcześniejszych badaniach prowadzonych w latach 2000-2002 za pomoca testów liścieniowych w Instytucie Genetyki Roślin Polskiej Akademii Nauk odsetek izolatów z tym allelem wynosił 59\%, natomiast w kolekcji zebranej w latach 2003-2004 już tylko 9\%. Najbardziej prawdopodobnym wythumaczeniem tak drastycznej zmiany składu populacji L. maculans jest zwiększenie powierzchni uprawy rzepaku ozimego z genem $R \operatorname{lm} 1$, podobnie jak to wykazano kilka lat temu we Francji (Rouxel i wsp. 2003).

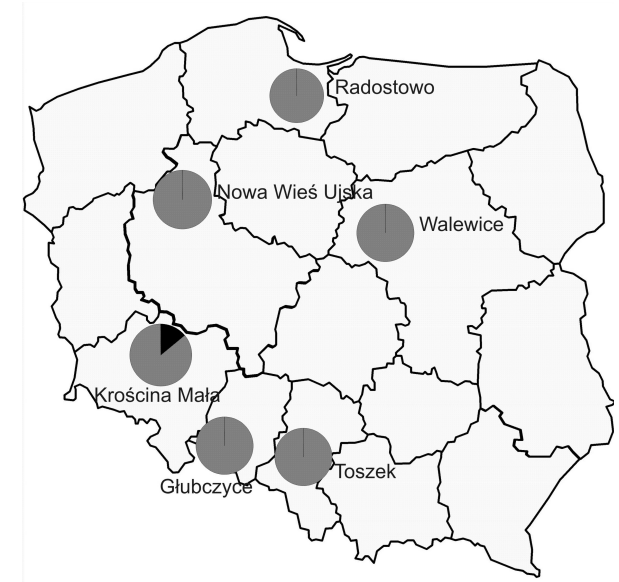

Rys. 4. Udział procentowy genów awirulencji AvrLm1 (czarny obszar) i genów wirulencji avrLm1 (szary obszar) w populacjach L. maculans w jesienią $2010 \mathrm{w}$ Polsce

Fig. 4. The percentage of avirulence genes AvrLml (black area) and virulence genes avrLml (grey area) in winter oilseed rape plants in autumn 2010 in Poland
W Walewicach i w Krościnie Małej stwierdzono po raz pierwszy $\mathrm{w}$ Polsce występowanie alleli avrLm6 (rys. 5). Jest to niewielki odsetek (8\%), co świadczy o tym, że odmiany posiadające geny Rlm6 mogą nadal skutecznie chronić rzepak przed L. maculans w Polsce. Należy jednak pamiętać, że ich masowe wprowadzenie będzie niewattpliwie przyczyną presji selekcyjnej wobec gatunku L. maculans w kierunku przełamania tej odporności.

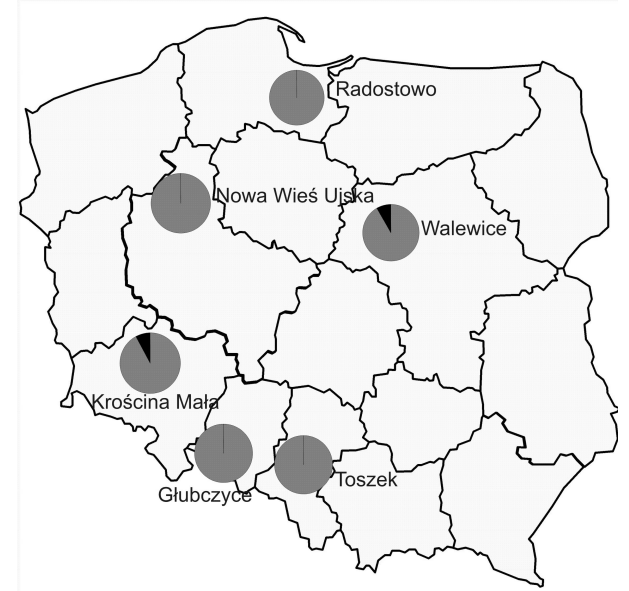

Rys. 5. Udział procentowy genów awirulencji AvrLm6 (szary obszar) i genów wirulencji avrLm6 (czarny obszar) w populacjach $L$. maculans w jesienią $2010 \mathrm{w}$ Polsce

Fig. 5. The percentage of avirulence gene AvrLm6 (grey area) and virulence gene avrLm6 (black area) in winter oilseed rape plants in autumn 2010 in Poland

\section{Wnioski / Conclusions}

1. Jesienią 2010 roku w Polsce $98 \%$ izolatów posiadało allel wirulencji avrLm1 przełamujący odporność genu $R \operatorname{lm} 1$. Dalsze wprowadzenie genu $R \operatorname{lm} 1 \mathrm{w}$ procesie hodowlanym nie ma obecnie uzasadnienia.

2. Po raz pierwszy w Polsce stwierdzono obecność allelu wirulencji avrLm6 w dwóch niezależnych lokalizacjach, pomimo iż w naszym kraju nie uprawia się odmian $\mathrm{z}$ genem Rlm6. W naturalnie występujących populacjach $L$. maculans obecne są już izolaty zdolne do przełamania tego genu odporności.

3. Zbliżony udział alleli MAT1.1 i MAT1.2 w pulach izolatów L. maculans $\mathrm{z}$ danego terenu świadczy o podobnym przystosowaniu obu typów kojarzeniowych tego grzyba do warunków klimatycznych i środowiskowych w Polsce. Możliwość swobodnego rozmnażania generatywnego gatunku L. maculans sprzyja utrzymywaniu wysokiego stopnia polimorfizmu genetycznego, tworzeniu nowych ras i ich szybkiej migracji do innych regionów geograficznych.

\section{Podziękowanie / Acknowledgements}

Dziękujemy firmie DuPont Poland Sp. z o.o. za udostępnienie materiałów do prowadzenia doświadczeń.

Niniejsze badania wykonano w ramach projektu Narodowego Centrum Nauki N N310 298439. 


\section{Literatura / References}

Ansan-Melayah D., Balesdent M.H., Buee M., Rouxel T. 1995. Genetic characterization of AvrLm1, the first avirulence gene of Leptosphaeria maculans. Phytopathology 85 (12): 1525-1529.

Balesdent M.H., Louvard K., Pinochet X., Rouxel T. 2006. A large scale survey of races of Leptosphaeria maculans occurring in oilseed rape in France. Eur. J. Plant Pathol. 114 (1): 53-65.

Chen C.Y., Fernando W.G.D. 2006. Prevalence of pathogenicity groups of Leptosphaeria maculans in western Canada and North Dakota, USA. Can. J. Plant Pathol. 28 (4): 533-539.

Cozijnsen A.J., Howlett B.J. 2003. Characterization of the mating-type locus of the plant pathogenic ascomycete Leptosphaeria maculans. Curr. Genet. 43 (5): 351-357.

Fitt B.D.L., Brun H., Barbetti M.J., Rimmer S.R. 2006. World-wide importance of phoma stem canker (Leptosphaeria maculans and L. biglobosa) on oilseed rape (Brassica napus). Eur. J. Plant Pathol. 114: 3-15.

Fudal I., Ross S., Gout L., Blaise F., Kühn M.L., Eckert M.R., Cattolico L., Bernard-Samain S., Balesdent M.H., Rouxel T. 2007. Heterochromatin-like regions as ecological niches for avirulence genes in the Leptosphaeria maculans genome: map-based cloning of AvrLm6. Mol. Plant Microbe Interactions 20 (4): 459-470.

Gout L., Fudal I., Kühn M.L., Blaise F., Eckert M., Cattolico L., Balesdent M.H., Rouxel T. 2006. Lost in the middle of nowhere: the AvrLm1 avirulence gene of the Dothideomycete Leptosphaeria maculans. Mol. Microbiol. 60 (1): 67-80.

Graham G.C., Mayers P., Henry R.J. 1994. A simplified method for the preparation of fungal genomic DNA for PCR and RAPD analysis. Biotechniques 16 (1): 48-50.

Jędryczka M. 2006. Epidemiologia i szkodliwość suchej zgnilizny kapustnych na rzepaku ozimym w Polsce. Rozprawy i Monografie IGR PAN 17, 150 ss.

Joosten M.H.A.J., De Wit P.J.G.M. 1988. Isolation, purification and preliminary characterization of a protein specific for compatible Cladosporium fulvum (syn. Fulvia fulva)-tomato interactions. Physiol. Mol. Plant Pathol. 33: 241-253.

Kaczmarek J., Brachaczek A., Jędryczka M. 2011. Wpływ terminu stosowania fungicydu zawierającego flusilazol na skuteczność ochrony rzepaku ozimego przed suchą zgnilizną kapustnych. Rośliny Oleiste - Oilseed Crops 32 (2): 153-166.

Karolewski Z. 1998. The influence of fungicides on Phoma lingam (Tode ex. Fr.) Desm. mycelium growth. IOBC/WPRS Bull. 21 (5): 33-39.

Laugé R., De Wit P.J.G.M. 1998. Fungal avirulence genes: structure and possible functions. Fungal Genet. Biol. 24 (3): $285-297$.

May G., Shaw F., Badane H., Vekemans X. 1999. The signature of balancing selection: fungal mating compatibility gene evolution. Proc. Natl. Acad. Sci. USA 96: 9172-9177.

Milgroom M.G. 1996. Recombination and the multilocus structure of fungal population. Annu. Rev. Phytopathol. 34 (1): $457-477$.

Rouxel T., Penaud A., Pinochet X., Brun H., Gout L., Delourme R., Schmit J., Balesdent M.H. 2003. A 10-year survey of populations of Leptosphaeria maculans in France indicates a rapid adaptation towards the Rlm 1 resistance gene of oilseed rape. Eur. J. Plant Pathol. 109 (8): 871-881.

Van de Wouw A.P., Stonard J.F., Howlett B.J., West J.S., Fitt B.D.L., Atkins S.D. 2010. Determining frequencies of avirulent alleles in airborne Leptosphaeria maculans inoculum using quantitative PCR. Plant Pathol. 59 (5): 809-818.

Venn L. 1979. The genetic control of sexual compatibility in Leptosphaeria maculans. Australas. Plant Pathol. 8 (1): 5-6.

Wubben J.P., Joosten M.H.A.J., De Wit P.J.G.M. 1994. Expression and localization of two in planta induced extracellular proteins of the fungal tomato pathogen Cladosporium fulvum. Mol. Plant Microbe Interactions 7 (4): 516-524. 